Original Research

\title{
The Effect of Ergonomic Gymnastics on Joint Pain in Community-Dwelling Elderly
}

\section{Martha Lowrani Siagian1, Anggi Hanafiah Syanif1, Andreas Wojtyla Sukur2, Beatric Maria Dwijayanti Baga2, and Ni Ketut Emi Rayuni2}

1Faculty of Nursing, Universitas Airlangga, Surabaya, Indonesia

2Institute of Health Science, William Booth, Surabaya, Indoensia

\begin{abstract}
Background: The aging process that occurs in the elderly is characterized by a decreasing immune system and physical impairment. The most common complaint is joint pain. The aim was to determine the effect of ergonomic gymnastics on the elderly who experienced joint pain.

Method: The samples totaled 110 respondents who had joint pain at KrembanganSurabaya obtained through the total sampling technique. The data was collected through observation sheets with one group pre-post-test design, and it was analyzed through the Wilcoxon text. The result showed that after 9 sessions of 60 minutes each for two months found that ergonomic gymnastics could influence the reduction of joint pain with a significance level of $0.00(\mathrm{p}<0.05)$.

Discussion: There were a decreasing number of respondents that felt moderate pain (82 to 44 ) and this automatically meant that there was an increasing number of mild pain respondents (28 to 66 ).

Conclusion: Exercising regularly and with the correct methods could provide an excellent benefit to maintain bodily health, especially to reduce joint pain in the elderly. It is expected that all health care providers in primary health services or in a private clinics should know and be able to conduct ergonomic gymnastics using the correct methods.
\end{abstract}

\section{ARTICLE HISTORY}

Received: Dec 26, 2019

Accepted: Dec 31, 2019

\section{KEYWORDS}

ergonomic gymnastics; joint pain; community dwelling, elderly

\section{CONTACT}

Martha Lowrani Siagian $\triangle$ martha.lowrani.siagia n-2018@fkp.unair.ac.id

$\equiv$ Faculty of Nursing, Universitas Airlangga, Surabaya, Indonesia

Cite this as: Siagian, M. L, Syarif, A. H, Sukur, A. W, Baga, B. M. D, and Rayuni, N. K. E. (2019). The Effect of Ergonomic Gymnastics on Joint Pain in Community-Dwelling Elderly. Jurnal Ners, 14(3si), 98-102 doi:http://dx.doi.org/10.20473/jn.v14i1.16995

\section{INTRODUCTION}

The increasing elderly population needs to get attention because the elderly group is a high-risk group that experiences an increase of various health problems, especially degenerative diseases(RI, 2006).The emergence of various diseases increases because of someone's age and because of that the body's immune system getting slightly down, that's why our body easily gets ill, becomes fatigued and can't do heavier or regular activity anymore. Old age is a natural process that cannot be avoided. The aging process that occurs in the elderly is characterized by biological deterioration that is seen by the symptoms of physical deterioration, among others including the skin begins to relax, wrinkles, gray hair, teeth begin to fall out, hearing and sight loss, and being more easily tired.

One disease that often occurs in old age is joint pain. Joint pain is a result of bone calcification or it can be due to other diseases (Muttaqin, 2010). Joint disorders in general provide symptoms in the form of pain that can disturb the patient, so the patients cannot work or move comfortably. Some of the factors that cause joint pain include the mechanisms of immunity, metabolic factors, age, excessive and repeated joint burden, genetic factors and environmental trigger factors (Uliya, S., Soempeno, B., 2007). Elderly people who experience joint pain disorders should exercise across a range of active motion so then there is no decrease in the range of motion in the elderly or no decrease in their muscle strength(Stanley, M \& Beare, 2010). Based on this problem, the researcher wanted to find some other ways to increase the independence of the elderly people by reducing the number of joint pain.

One of the exercises for active motion is by doing ergonomic exercises. Ergonomic gymnastics is one method that is practical and effective at maintaining 
bodily health. Ergonomic gymnastic movements are movements that are in accordance with the rules of creation of the body and this movement is like a prayer movement. Ergonomic gymnastics can directly open, cleanse and activate all body systems such as the cardiovascular, urinary and reproductive systems (Liu, Wan, Zhou, Feng, \& Shang, 2017). Ergonomic gymnastics consists of movements that resemble prayer movements so then the elderly can easily apply these gymnastic movements in their daily life (Gerais, 2017). Based on the preliminary study at the Wredha Mojopahit orphanage, Mojokerto Regency, it was obtained that 80 elderly individuals had joint disease (joint pain) by around 70\%.

There are several service researchers at the Krembangan Health Center that are concerned with the elderly people who have joint pain. Based on the research conducted by Wratsongko, there is the effect of ergonomic exercise on pain complaints referring to the increasing range of motion in elderly people who have experience of rheumatic pain at the Bhakti Dharma in Surakarta Hospital(Wratsongko, 2010). According to the World Health Organization (WHO), they reported that $20 \%$ of the world's population is affected by joint pain. From the study on the socio-economic and health conditions of the elderly carried out by the National Commission on Elderly in 10 provinces in 2006, it became known that the majority of illnesses suffered by the elderly were $69.39 \%$ for joint pain, after which came hypertension, anemia, and cataracts (Walker, Sibley, Carter, \& Hurley, 2017). According to the District Health Office data in 2010, the number of elderly people suffering from joint disease was $2.3 \%$. Based on the results of a recent study about the prevalence of joint pain in Indonesia, it has reached $23.6 \%$ to $31.3 \%$. Based on health diagnosis and symptoms, the national prevalence of joint disease is $30.3 \%$, and the prevalence of joint disease in East Java specifically is 30.9\% (Zeng, Q.Y., Chen, R., Darmawan, 2008). Therefore the authors are interested in conducting research on the effect of ergonomic exercise on the elderly who experience joint pain in the Krembangan Health Center for the elderly.

\section{MATERIALS AND METHODS}

\section{Research Design, Population, Sample, and Variables}

The design used was one group pre-post test design. The population of this research was all of the elderly that visited the Primary Heath Service regularly for routine activities or to check their health condition. The sample obtained was 110 respondents through the total sampling technique. This research was conducted at the elderly care service in Krembangan (Integrated health service for an elderly) from September 3rd - October 29th, 2018. The inclusion criteria in this research were as follows: 1) elderly patients with an average age $<60$ years old and $>71$ years old, 2) all genders (Male and Female), 3) elderly with moderate and mild pain, 4) all levels of education (from elementary up until a Bachelor's degree), 5) all working statuses (private/public employee or retired), 6) they were able to communicate verbally well, and they were able to read, and write and 7) they were willing to participate and had a strong commitment to join us for two months. The exclusion criteria were 1) the elderly who had severe pain and 2) the elderly who visited the elderly care service centre irregularly. The independent variable was the application of ergonomic gymnastics and the dependent variable was joint pain.

\section{Instruments}

The research used a leaflet module as the media that was given to the respondents. The module consisted of information about the aging process, diet, common behaviors for the elderly, bein elderly with regular activity or elderly with less activity, and elderly nutrition status (underweight, normal, overweight, obese). This was in addition to simple instructions about ergonomic exercise. Other instruments that were used included an observation sheet that contained how long the elderly had to be able to follow the instructions and VDS (verbal descriptor scale) for measuring the joint pain scale(Walker et al., 2017), which was modified and translated into the Indonesian language. The respondents were asked to show how severe their joint pain was on a 1-10 scale and this scale indicated mild pain, moderate pain, and severe or uncontrolled pain. After we finished the interviews and the observation, we demonstrated ergonomic exercise, and asked them to follow it step by step.

\section{Research Procedures and Analysis}

This research was carried out in collaboration with Krembangan, Surabaya Primary Health Service in order to increase the knowledge of the elderly people surrounding the public health service and to encourage the elderly to be more active when visiting through empowerment and health education. The research passed the ethical review and obtained an Ethical Approval certificate, which was No. 197/STIKesWB/PPM/2018 issued by the Health Research Ethics Committee of Institute of Health Science for the Nursing department, William Booth Surabaya in East Java Province, Indonesia. The research was conducted with one treatment group by providing some leaflets and demonstrate ergonomic exercises with some observations and interviews (questions about their pain scale) within a module for 9 meetings across 2 months, which were conducted once a week for 60 minutes, with an evaluation before and after the treatment (pre-post test design).The first week was the introduction to the programs, and an ergonomic gymnastics demonstration and leaflet were given to the respondents. Weeks 2 - 8 provided the health education, explored the elderly comprehension of being elderly and all the related problems, ergonomic gymnastics were demonstrated and there was an observation of the pain scale. Week 
9 was monitoring evaluation and ergonomic gymnastic demonstration. Data were analyzed by using IBM SPSS Statistic 24. The statistical analysis used the Wilcoxon Signed Rank Test. The confidence interval was $100 \%$ with $\mathrm{p}=0.00$.

\section{RESULTS}

Characteristics of the respondents as shown in Table 1 . The majority of the respondents were aged 61-70 years, female, educated to elementary level and unworking/retired. From the data, we can assume that this is typical of the elderly people in Krembangan; this may influence how their thinking and interpretation about pain. All of the participants - 110 elderly in total - were very pleasant toward the program.

It can be seen that the results of the research at elderly care service in Krembangan Surabaya before the ergonomic exercise for all of the elderly respondents was that those in mild pain totaled 28 people and that those with moderate pain totaled 82 people. After the implementation of ergonomic gymnastics, mild pain was experienced by 66 people and moderate pain was experienced by 44 people. The data was analyzed using the Wilcoxon statistical test with a significance degree of $\mathrm{p}<0.05$ and a significance level of $p=0.00$. Thus, $\mathrm{H} 1$ was accepted, where the conclusion was that there is some effect from doing ergonomic gymnastics on the elderly who experienced joint pain at the elderly care service in Krembangan, Surabaya.

\section{DISCUSSION}

The VDS scale with observations and an interview approach explains the basic principles of the prevention of joint pain in the elderly(Lincoln, Radford, Game, \& Jeffcoate, 2008) to prevent a higher risk of injury. It is highly dependent on the elderly people by giving them solutions and interventions focused on reducing joint pain by providing integrated health education and ergonomic gymnastics demonstration(Schaper, Van Netten, Apelqvist, Lipsky, \& Bakker, 2017). The aging process will cause anatomical, physiological, and biochemical changes in the body so this affect the body's functions and abilities as a whole (Primana, 2006). All systems in the body experience setbacks, including the musculoskeletal system, in which the elderly often experience rheumatism, gout, joint pain and lumbar pain (Pudjiastuti, S.S., \& Utomo, 2003). One of the other factors in the musculoskeletal system is the bone loss in terms of density and the more fragile knee and wrist movements. The wrist and finger movements become limited, the joints enlarge and become stiff, the tendons constrict, and they experience sclerosis and an atrophy of muscle fibers (muscle fibers shrinking). Movement becomes sluggish, as the muscles become cramped and tremor. A common disease that often occurs in old age is joint pain. There was evidence of this happening when the
Table 1. Characteristics of the Respondents

\begin{tabular}{lcc}
\hline \multirow{2}{*}{ Characteristics } & \multicolumn{2}{c}{ Treatment Group } \\
\cline { 2 - 3 } Age & $\mathbf{n}$ & $\mathbf{\%}$ \\
<60year & 8 & 7.3 \\
61-70 year & 79 & 71.8 \\
$\quad$ 71 year & 23 & 20.9 \\
Gender & & \\
$\quad$ Male & 26 & 23.6 \\
Female & 84 & 76.4 \\
Level of Education & & \\
Elementary & 34 & 30.9 \\
Junior High & 10 & 9.09 \\
Senior High & 28 & 25.4 \\
Diploma & 25 & 22.7 \\
Bachelor & 13 & 11.9 \\
Working Status & & \\
Yes (Private) & 14 & 12.7 \\
Yes (Public) & 3 & 2.7 \\
No & 93 & 84.6 \\
\hline
\end{tabular}

Table 2. Effect of Ergonomic Gymnastics on Joint Pain in the Elderly

\begin{tabular}{ccccc}
\hline Variable & \multicolumn{2}{c}{ Pre } & \multicolumn{2}{c}{ Post } \\
\hline Joint Pain & $\mathrm{n}$ & $(\%)$ & $\mathrm{n}$ & $(\%)$ \\
Mild Pain & 28 & 26 & 66 & 60 \\
Moderate Pain & 82 & 74 & 44 & 40 \\
Total & 110 & 100 & 110 & 100 \\
\multicolumn{2}{c}{ Statistic test results - Wilcoxon $\mathrm{p}=0$} \\
\hline
\end{tabular}

researcher engaged in the the observation-interview with the respondent to look or find out the scale of the pain in the elderly at the elderly care service focused on in Krembangan-Surabaya. When the researchers asked the respondents questions, mostly the elderly people answered as to when they had joint pain. Ordinarily, they just let it go and rested for a while, minimizing their activity.

The respondents who were younger than 60 years old totaled 8 people (7\%), those aged $61-70$ years old totaled 79 people $(72 \%)$ and those who were more than 71 years old totaled 23 people (20\%). Almost $8 \%$ of people aged 50 years and over had complaints about their joints, especially rheumatic pain and aches. All of the elderly people often suffered from pain in the joints. This is because the musculoskeletal system decreases in its functions due to changes in the collagen. The impact of this change decreases joint flexibility in addition to the erosion of the joint capsules resulting in decreased joint movement and pain(Albargawi, Snethen, Gannass, \& Kelber, 2017).

The majority gender in this study was mostly female, amounting to 84 people (76\%). Women are susceptible to severe osteoarthritis caused by a decrease in the estrogen hormone during menopause. Hormones play a role in the loss of bone mass which results in joint pain sensations in the elderly(Sanou et al., 2018). Other research shows that the incidence rate of joint pain is greater in women, which is caused by a dramatic decrease in estrogen hormone levels. Meanwhile in men, the hormone estrogen decreases very slowly. The decrease in the hormone estrogen plays an important role in maintaining bones. The protection from pain also diminishes as women get 
older. In women, the hips are more shaped so the buildup of fat in the hips increases the burden of the joints and muscles in the legs. This causes joint pain, while men have a straighter posture and it is the male tendency to maintain an ideal posture(Vivi Meliana Sitinjak, Maria Fudji Hastuti, 2016).

For level of education, 34 of the elderly were elementary school graduates (30\%), 1 graduated junior high school (10\%), 3 were senior high school graduates (25\%), $25(22.7 \%)$ had a diploma and 13 $(12 \%)$ had an undergraduate program background. Education status affects the opportunity to obtain information about the management of disease. Elderly people who have a low level of knowledge can influence the limited information available when getting the knowledge to prevent the disease, to protect themselves, and on how to manage their own pain to improve their health status. This is what causes the elderly who experience joint pain to be supportive of the daily activities that are needed [16]. The level of education of a person is very influential on changes in their attitude and the behaviors related to healthy living. Higher levels of education will make it easier for a person or community to absorb information and to implement it in daily behavior and lifestyle, especially in terms of health. Based on the information obtained by the researchers through questions and answers with the respondents, the respondents said that they always tried to maintain or lessen the level of their joint pain by exercising.

Looking into working status found that most of the elderly people were not working, although some of them were house-wives, totaling as many as 93 people (85\%) out of the 110 respondents. According to (Muttaqin, 2010), activity will also activate the immune system and prevent inflammation in the joints. One of the factors that impacts on joint pain in the elderly is physical exercise, as it trains the body to move which will have an impact on the production of synovial fluid which functions as a lubricant and prevents friction in the joints. This shows that if the elderly do not carry out activities such as exercise or gymnastics, then the lubricant in the joint will decrease and cause stiffness. Conversely, if the elderly often exercise, then the synovial fluid will increase and reduce the risk of injury, which will prevent joint pain in the elderly. It is very important to maintain health by doing bodily exercises safely to avoid injury. At the time that the aging process happens, their physical activity level will be decreasing due to physical deterioration and this could promote bone calcification in the long term if there are no interventions. Exercise is very beneficial for improving blood circulation, losing weight and producing synovial fluid to reduce joint pain in the elderly.

Physical activity is included in research such as ergonomic gymnastics to maintain blood circulation and to prevent bone contracture. Maintaining physical activity will increasing the sensitivity of the insulin receptors in the active muscle(Vivi Meliana Sitinjak, Maria Fudji Hastuti, 2016). The main problem that occurs in the elderly is the occurrence of joint pain, which is caused by the aging process and the loss of synovial fluid from the joint. This means that the bones rub easily against each other. When a person performs physical activity, there will be a muscle contraction which will eventually make it easier for glucose to enter the cell(Jankowska-Polaska et al., 2015). This means that when a person engages $\mathrm{n}$ physical activity, it will reduce their insulin resistance and eventually reduce blood sugar levels. There are other factors that influence blood sugar levels. In addition to SGFDP implementation, there are several things that cause blood sugar to rise, namely a lack of exercise, an increased amount of food consumed, increased stress and emotional factors, weight gain and age, and the impact of treatment from drugs, such as steroids(Iljaž, Brodnik, Zrimec, \& Cukjati, 2017).

The driving factor is that obtained from the closest person and social support given to the individual such as their family, friends and teachers, and especially in this case, the health workers who can strengthen the behavior of the elderly. With the support provided by their closest people, it is expected to encourage behavior change(Nursalam, 2016). In the prevention of joint pain in the elderly, ergonomic gymnastics can be one of the solutions that consist of the identification of the risk of joint pain. Routine examinations of their exercise and giving health education to the patients about diet and all of the problems related to being elderly will increase the meaning of life of an elderly person.

\section{CONCLUSION}

Ergonomic exercises can cause a decrease in joint pain in the elderly in the care service provided in Krembangan Surabaya. Elderly people experience joint pain due to their synovial fluid being reduced due to the aging process. Sharing information and the attention given by the nurses with regular meetings can increase their knowledge and cause behavior changes in the elderly to encourage them to take positive actions. This proved that ergonomic gymnastic can prevent or reduce joint pain in the elderly by doing this type of exercise regularly. Family with elderly members inside should maintain a good lifestyle including good food, a balanced diet, and routine exercise and activities. The next researchers should be able to improve the treatment of joint pain in the elderly based on their culture and by evaluating the qualitative data.

\section{REFERENCES}

Albargawi, M., Snethen, J., Gannass, A. Al, \& Kelber, S. (2017). Relationship between person 's health beliefs and diabetes self-care management regimen. Journal of Vascular Nursing, 1-6. https://doi.org/10.1016/j.jvn.2017.07.002

Gerais, M. (2017). Ergonomics posture and movement analyses of supermarket checkout operators in 
the city of. 123-135.

Iljaž, R., Brodnik, A., Zrimec, T., \& Cukjati, I. (2017). EHealthcare For Diabetes Mellitus Type 2 Patients - A Randomised Controlled Trial In Slovenia EZdravstvena Oskrba Bolnikov S Sladkorno Boleznijo Tipa Ii - Randomizirana Kontrolirana Raziskava V Sloveniji. 56(3), 150-157.

Jankowska-Polaska, B., Fal, A. M., Uchmanowicz, I., Sen, M., Polanski, J., \& Kurpas, D. (2015). Influence of organized diabetic education on self-control and quality of life of patients with type 2 diabetes. International Journal of Diabetes in Developing Countries, 35, 79-87. https://doi.org/10.1007/s13410-014-0253-4

Lincoln, N. ., Radford, K. ., Game, F. ., \& Jeffcoate, W. . (2008). Education for secondary prevention of foot ulcers in people with diabetes: A randomized controlled trial. Diabetologia, 51, 1954-1961.

Liu, C., Wan, Q., Zhou, W., Feng, X., \& Shang, S. (2017). Factors associated with balance function in patients with knee osteoarthritis: An integrative review. International Journal of Nursing Sciences. https://doi.org/10.1016/j.ijnss.2017.09.002

Muttaqin, A. (2010). Buku Ajar Asuhan keperawatan Klien Dengan Gangguan Sistem Imunologi. Jakarta: Salemba Medika.

Nursalam. (2016). Metodologi Penelitian Ilmu Keperawatan. Jakarta: Salemba Medika.

Primana, D. A. (2006). Fleksibilitas Sendi Lanjut Usia Pada Berbagai Kompensasi Tubuh. Jurnal Knowledge Management (JKM), 06-01, 1-12.

Pudjiastuti, S.S., \& Utomo, B. (2003). Fisioterapi Pada Lansia. Jakarta: EGC.

RI, D. (2006). Pharmaceutical Care Untuk Hipertensi. Jakarta.

Sanou, A. S., Diallo, A. H., Holding, P., Nankabirwa, V.,
Engebretsen, I. M. S., Ndeezi, G., ... KashalaAbotnes, E. (2018). Association between stunting and neuro-psychological outcomes among children in Burkina Faso, West Africa. Child and Adolescent Psychiatry and Mental Health, 12(1), 1-10. https://doi.org/10.1186/s13034-018-0236-1

Schaper, N. C., Van Netten, J. J., Apelqvist, J., Lipsky, B. A., \& Bakker, K. (2017). Prevention and management of foot problems in diabetes: A Summary Guidance for Daily Practice 2015, based on the IWGDF guidance documents. Diabetes Research and Clinical Practice, 124, 8492. https://doi.org/10.1016/j.diabres.2016.12.007 Stanley, M \& Beare, P. . (2010). Buku Ajar Keperawatan Gerontik (2nd ed.). Jakarta: EGC.

Uliya, S., Soempeno, B., \& K. B. M. W. (2007). Pengaruh Latihan Range of Motion (ROM) Terhadap Fleksibilitas Sendi Lutut Pada Lansia di Panti Wreda Wening Wardoyo Ungaran. Jurnal Media Ners, 1.2, 72-79.

Vivi Meliana Sitinjak, Maria Fudji Hastuti, A. N. (2016). Pengaruh Senam Rematik Terhadap Perubahan Skala Nyeri Pada Lanjut Usia Dengan Osteoartritis Lutut. Jurnal Keperawatan Padjajaran, 4(2), 139-150.

Walker, A., Sibley, F., Carter, A., \& Hurley, M. (2017). Improving access to better care for people with knee and / or hip pain: service evaluation of allied health professional - led primary care. 111. https://doi.org/10.1002/msc.1189

Wratsongko, M. (2010). Senam Ergonomik dan Pijat Getar Saraf. Jakarta: EGC.

Zeng, Q.Y., Chen, R., Darmawan, J. (2008). Rheumatic Diseasesi in China. Arthritis Research and Theraphy, 10. 